\title{
Silage preparation and fermentation quality of natural grasses treated with lactic acid bacteria and cellulase in meadow steppe and typical steppe
}

\author{
Meiling Hou ${ }^{1, a}$, Ge Gentu ${ }^{1, a}$, Tingyu Liư ${ }^{2}$, Yushan Jia ${ }^{1, *}$, and Yimin Cai ${ }^{3, *}$
}

\author{
* Corresponding Authors: Yushan Jia \\ Tel: +86-4714318929, Fax: +86-4714312569, \\ E-mail: jys_nm@sina.com \\ Yimin Cai \\ Tel: +81-298388648, Fax: +81-298388648, \\ E-mail: cai@affrc.go.jp \\ 'Laboratory of Grassland Resources, Ministry of \\ Education, P.R. of China, College of Grassland, \\ Resources and Environment, Inner Mongolia \\ Agricultural University, Hohhot 010019, China \\ ${ }^{2}$ College of Agriculture, Inner Mongolia University of \\ Nationalities, Tongliao 028000, China \\ ${ }^{3}$ Institute of Livestock and Grassland Science, NARO, \\ Tsukuba, Ibaraki 305-0901, Japan
}

a These authors contributed equally to this work. Submitted Jul 27, 2016; Revised Sept 5, 2016; Accepted Sept 20, 2016
Objective: In order to improve fermentation quality of natural grasses, their silage preparation and fermentation quality in meadow steppe (MS) and typical steppe (TS) were studied. Methods: The small-scale silages and round bale silages of mixed natural grasses in both steppes were prepared using the commercial lactic acid bacteria (LAB) inoculants Chikuso-1 $(\mathrm{CH}$, Lactobacillus plantarum) and cellulase enzyme (AC, Acremonium cellulase) as additives.

Results: MS and TS contained 33 and 9 species of natural grasses, respectively. Stipa baicalensis in MS and Stipa grandi in TS were the dominant grasses with the highest dry matter (DM) yield. The crude protein $(\mathrm{CP})$, neutral detergent fiber and water-soluble carbohydrate of the mixed natural grasses in both steppes were $8.02 \%$ to $9.03 \%, 66.75 \%$ to $69.47 \%$, and $2.02 \%$ to $2.20 \%$ on a DM basis, respectively. All silages treated with LAB and cellulase were well preserved with lower $\mathrm{pH}$, butyric acid and ammonia- $\mathrm{N}$ content, and higher lactic acid and $\mathrm{CP}$ content than those of control in four kinds of silages. Compared with $\mathrm{CH}$ - or AC-treated silages, the $\mathrm{CH}+$ AC-treated silages had higher lactic acid content.

Conclusion: The results confirmed that combination with $\mathrm{LAB}$ and cellulase may result in beneficial effects by improving the natural grass silage fermentation in both grasslands.

Keywords: Meadow Steppe; Natural Grass; Silage Fermentation; Typical Steppe

\section{INTRODUCTION}

Meadow steppe (MS) and typical steppe (TS) are important natural steppes that are widely distributed in temperate semi-arid continental climate region and the northern hemisphere boreal and temperate. In China, they are distributed in the northeast, Inner Mongolia, Xinjiang, Qinghai and Tibet Plateau. These steppes play an important role in animal production. However, both steppes are limited in their hay production due to the cold, dry climate, regardless of water use [1]. They occupy about 400.02 million $\mathrm{km}^{2}$ but can only support 13.62 million tons of hay, which provides about only $42 \%$ of the animal feed needed in the winter and spring. Local farmers usually begin storing grass in mid-August. During harvest and storage, dry matter (DM) and crude protein (CP) will be lost [2]. Previously, interest has shifted toward natural grass silage as a main feed source for ruminant animals. Not only can it be prepared ahead of time, in late July to early August, which preserves nutritional value, but it can also extend the retention time, facilitating fodder provision throughout the year, regardless of the weather [3].

It is usually difficult to prepare a good silage fermentation from natural grasses because of their lower moisture, water-soluble carbohydrate (WSC) content and lactic acid bacteria (LAB) counts, as well as their higher lactate buffering capacity [4]. Some studies have tried to solve the problem of poor fermentation by using silage additives, such as LAB and cellulase $[5,6]$, which 
are widely used for silage preparation. The cellulase can enhance fiber degradation and increase WSC content as a substrate for LAB [7], which can convert WSC into lactic acid [8,9]. As a result, the silage $\mathrm{pH}$ is reduced and the forage well preserved. However, limited information is available on the preparation and fermentation of natural grass silage treated with microbiological additives in the both grasslands. The present study examined the grassland population, DM yield, fermentation quality, and chemical composition of natural grasses in MS and TS environments. To improve fermentation quality, small-scale silages and round bale silages of mixed natural grasses in both steppes were prepared using LAB inoculant and cellulase enzyme.

\section{MATERIALS AND METHODS}

\section{Grassland population and yield analysis}

Natural grasses were harvested at full-bloom stage from Hulunbuir MS $\left(48.27^{\circ} \mathrm{N}, 119.44^{\circ} \mathrm{E}\right)$, and Xilingol TS $\left(43.46^{\circ} \mathrm{N}, 115.13^{\circ} \mathrm{E}\right)$, Inner Mongolia, China on 24 July 2014. Grasses were harvested in three clipping grasslands with sample lines at $500 \mathrm{~m}$ length within the fenced exclosure. According to the specific locations, total 10 sample plots in every $50 \mathrm{~m}$ were set with signed global positioning system data on each sample line, we took the quadrat with $1 \mathrm{~m} \times 1 \mathrm{~m}$ to determine the grass species, and three replicated gradients were used to eliminated the random error. Species density was calculated by dividing the number of individuals in the quadrat [10]. Species cover was determined as the proportion ( $0 \%$ to $1 \%, 1 \%$ to $5 \%, 5 \%$ to $10 \%, 10 \%$ to $20 \%, 20 \%$ to $40 \%, 40 \%$ to $60 \%, 60 \%$ to $100 \%$ ) of the quadrat covered by its canopy [11]. The biomass production of species was determined by the average weight of all quadrates, and the grasses were oven-dried at $65^{\circ} \mathrm{C}$ for $48 \mathrm{~h}$ to estimate the DM biomass [12].

\section{Silage preparation}

The grasses in both steppes were harvested at full-bloom stage. Silages were prepared using small-scale fermentation and round bale system. A commercial LAB inoculant Chikuso-1 (CH, Lactobacillus plantarum, Snow Brand Seed Co., Ltd, Sapporo, Japan) and a commercial cellulase enzyme (AC, acremonium cellulase, Meiji Seika Pharma Co., Ltd, Tokyo, Japan) were used as silage additives. AC is produced from Acremonium cellulolyticus, the main composition are glucanase and pectinase, carboxymethylcellulase activity is $7,350 \mathrm{U} / \mathrm{g}$. The $\mathrm{LAB}$ were inoculated at 20 $\mathrm{mg} / \mathrm{kg}$ as $1.00 \times 10^{5}$ colony forming unit (cfu)/g on a fresh matter (FM) basis. AC was added at $10 \mathrm{mg} / \mathrm{kg}$ of FM. Silage treatments were designed as control, $\mathrm{CH}, \mathrm{AC}$, and $\mathrm{CH}+\mathrm{AC}$. The $\mathrm{LAB}$ and cellulase were diluted with deionized water, and the additive solution was sprated using an electronic sprayer (Solo, 417, Hamburg, Germany) for addition of round bale silage. For small-scale silage preparation, a hand-held sprayer (SX-MD16E-2, Shixia Holding Co., Ltd, TaiZhou, China) was used for addition. The same amount of deionized water was sprayed on the control treatment. The small-scale silages were prepared by using polyethylene jars (1L capacity, Changgan Co., Ltd, Huizhou, China). Grasses were cut into $10 \mathrm{~mm}$ length by using a chopper machine (130DX, ARS Co., Ltd, Osaka, Japan), and were mixed well with or without $\mathrm{LAB}$ and cellulase, maximum $1 \mathrm{~kg}$ of grasses were packed into the jars. Round bale silages were made using a Rollant round baler (375 RC, Harsewinkel, Germany). The natural grasses in the field were cut and packed continuously into the baler, and these bales were produced with a maximum weight of $200 \mathrm{~kg}$, and approximately $1.20 \mathrm{~m}$ diameter and $1.20 \mathrm{~m}$ length. These bales were transported to storage place and four layers of polypropylene films $(0.03 \mathrm{~mm}$, the DOW Chemical Company, Hayward, CA, USA) were immediately wrapped by using a round bale wrapper (SW5000, Vermeer Manufacturing Co., Ltd, Pella, IA, USA). These bales and jars were stored in outdoor and indoor at temperature $20^{\circ} \mathrm{C}$ to $26^{\circ} \mathrm{C}$. Three replicates per treatments were opened at 60 days of ensiling, fermentation quality and chemical composition were analyzed.

\section{Chemical analysis}

The fermentation products of silage were analyzed by using coldwater extract as described by Cai [13]. Silage (10 g) was blended with $90 \mathrm{~mL}$ deionized water and kept in a refrigerator at $4^{\circ} \mathrm{C}$ for $24 \mathrm{~h}$ [14]. The $\mathrm{pH}$ was measured with a glass electrode $\mathrm{pH}$ meter (STARTER 100/B, OHAUS, Shanghai, China), the ammonia-N content was analyzed by using steam distillation of the filtrates [13], the concentration of organic acid were measured by high performance liquid chromatography methods as described by Cai [13]. The DM content of the samples were oven dried at $65^{\circ} \mathrm{C}$ for 48 h, CP and organic matter (OM) were analyzed by Horwitz and Latimer [15] method. The content of neutral detergent fiber (NDF) and acid detergent fiber (ADF) were determined as described by Van Soest et al [16]. The WSC content was determined as described by Thomas [17].

\section{Statistical analyses}

Statistical analyses of chemical composition and silage fermentation were performed by one-way analysis of variance using the general linear model procedure of SAS version 9.1 (SAS Institute Inc, 2003). The differences between means were assessed by Tukey's multiple comparison tests at a significant level of $\mathrm{p}<0.05$ [18].

\section{RESULTS}

\section{Grassland population and yield of natural grasses}

Grassland population and DM yield of MS and TS are shown in Table 1. Based on the DM yield, Stipa Baicalensis, Leymus chinensis, Serratula centauroides, Achnatherum sibiricum, and Cleistogenes squarrosa were the dominant grasses in MS. The DM yield at a high level of order were $163.29 \mathrm{~kg} / \mathrm{hm}^{2}$ for Stipa Baicalensis (10.66\%, proportion of total DM yields), 107.23 for 
Table 1. Dry matter yield of natural grasses in meadow steppe and typical steppe

\begin{tabular}{|c|c|c|c|c|}
\hline Grass species & English name & Local name & $\begin{array}{l}\text { DM yield } \\
\left(\mathrm{kg} / \mathrm{hm}^{2}\right)\end{array}$ & $\begin{array}{c}\text { Proportion } \\
\text { of total DM } \\
\text { yield }(\%)\end{array}$ \\
\hline \multicolumn{5}{|l|}{ Meadow steppe } \\
\hline Stipa Baicalensis Roshev & Baical Needgrass & Bei Jiaerzhenmao & $163.29 \pm 0.02$ & 10.66 \\
\hline Leymus chinensis (Trin.) Tzvel. & China Leymus & Yang Cao & $107.23 \pm 0.41$ & 7.00 \\
\hline Serratula centauroides L. & Common Scawwort & Ma Huatou & $93.77 \pm 0.02$ & 6.12 \\
\hline Achnatherum sibiricum (L.) Keng & Siberian Jijigrass & Yu Mao & $92.72 \pm 0.28$ & 6.05 \\
\hline Cleistogenes squarrosa (Trin.) Keng & Scabrous Hideseedgrass & Cao Yinzica & $85.33 \pm 0.79$ & 5.57 \\
\hline Pulsatilla turczaninovii Kryl. et Serg. & Slenderleaf Pulsatilla & Xi Yebaitouweng & $84.34 \pm 0.12$ & 5.50 \\
\hline Carex tristachya Thunb. & Threespike Sedge & Tai Cao & $74.36 \pm 0.03$ & 4.86 \\
\hline Poa annua L. & Annual Bluegrass & Zao Shuhe & $56.42 \pm 4.98$ & 3.68 \\
\hline Melissilus ruthenicus (L.) Peschkova (Trigonella ruthenica L.) & Ruthenia Medic & Bian Xudou & $52.58 \pm 0.55$ & 3.43 \\
\hline Adenophora stenanthina (Ledeb.) Kitagawa & Longstyle Ladybell & Chang Zhushashen & $52.22 \pm 0.44$ & 3.41 \\
\hline Astragalus adsurgens Pall. & Erect Milkvetch & Xie JingHuangqi & $52.17 \pm 0.15$ & 3.41 \\
\hline Thalictrum aquilegifolium L. var. sibiricum Regel et Tiling & Siberia Golumbine Meadowrue & Tang Songcao & $49.16 \pm 0.99$ & 3.21 \\
\hline Artemisia frigida (Willd.) Bess & Fringed Sagebrush & Leng Hao & $46.67 \pm 1.63$ & 3.04 \\
\hline Iris ventricosa Pall. & Cystoidflower Swordflag & Nang Huayuanwei & $44.74 \pm 3.55$ & 2.92 \\
\hline Astragalus melilotoides Pall. & Sweetcloverlike Milkvetch & CaoMuxizhuanghuangqi & $44.32 \pm 0.36$ & 2.89 \\
\hline Potentilla acaulis L. & Stemless Cinquefoil & Xing Maoweilingcai & $38.92 \pm 0.93$ & 2.54 \\
\hline Oxytropis myriophylla (Pall.) DC. & Leafy Crazyweed & Duo Yejidou & $38.25 \pm 1.27$ & 2.50 \\
\hline Carex chinensis Retz. & China Sedge & Ri Yinjian & $37.25 \pm 0.39$ & 2.43 \\
\hline Bupleurum scorzonerifolium Willd. & Red Thorowax & Hong Chaihu & $35.45 \pm 0.12$ & 2.31 \\
\hline Koeleria cristata (L.) Pers. & Junegrass & Qia Cao & $29.02 \pm 2.05$ & 1.89 \\
\hline Ixeris polycephala Cass. & China Ixeris & Ku Maicai & $28.34 \pm 0.12$ & 1.85 \\
\hline Veronica incana L. & White Speedwell & Bai Popona & $26.42 \pm 0.02$ & 1.73 \\
\hline Gentiana dahurica Fisch. & Dahuria Gentian & Da Wulilongdan & $24.39 \pm 0.44$ & 1.59 \\
\hline Scorzonera Subacaulis (Regel.) Lipsch. & Low Serpentroot & Ai yacong & $23.92 \pm 3.09$ & 1.56 \\
\hline Cymbaria dahurica L. & Dahur Cymabria & Da Wulixinba & $21.35 \pm 0.28$ & 1.39 \\
\hline Sanguisorba officinalis L. & Garden Burnet & Di Yu & $21.33 \pm 0.27$ & 1.39 \\
\hline Scutellaria scordifolia Fisch. ex Schrenk. & Twinflower Skullcap & Bing Touhuangqin & $20.35 \pm 0.13$ & 1.33 \\
\hline Agropyron cristatum (L.) Gaertn. & Wheatgrass & Bing Cao & $18.29 \pm 1.74$ & 1.94 \\
\hline Heteropappus altaicus (Willd.) Novopokr & Altal Puppyflower & A Ertaigouwahua & $16.33 \pm 1.36$ & 1.07 \\
\hline Galium verum L. & Yellow Bedstraw & Peng Zicai & $15.78 \pm 0.05$ & 1.03 \\
\hline Silene conoidea L. & Conical Catchfly & Mai Pingcao & $13.34 \pm 0.23$ & 0.87 \\
\hline Allium tenuissimum L. & Thinleaf Leek & Xi Yejiu & $12.07 \pm 0.06$ & 0.79 \\
\hline Potentilla tanacetifolia Willd. ex Schlecht. & Tansyleaf Cinquefoil & Ju Yeweilingcai & $11.29 \pm 1.52$ & 0.74 \\
\hline \multicolumn{5}{|l|}{ Typical steppe } \\
\hline Stipa grandis P. Smirn. & Larch Needlegrass & Da Zhenmao & $1,147.04 \pm 0.19$ & 61.27 \\
\hline Stipa krylovii Roshev & Altai Needlegrass & Ke Shizhenmao & $428.66 \pm 0.76$ & 22.90 \\
\hline Cleistogenes squarrosa (Trin.) Keng & Scabrous Hideseedgrass & Cao Yinzicao & $122.17 \pm 0.04$ & 6.53 \\
\hline Anemarrhena asphodeloides Bunge & Anemarrhena & Zhi Mu & $79.96 \pm 1.49$ & 4.27 \\
\hline Leymus chinensis (Trin.) Tzvel. & China Leymus & Yang Cao & $47.84 \pm 0.46$ & 2.56 \\
\hline Allium tenuissimum $\mathrm{L}$. & Thinleaf Leek & Xi Yejiu & $31.32 \pm 0.55$ & 1.67 \\
\hline Agropyron cristatum (L.) Gaertn. & Wheatgrass & Bing Cao & $12.25 \pm 0.04$ & 0.65 \\
\hline Thalictrum aquilegifolium L. var. sibiricum Regel et Tiling & Siberia Golumbine Meadowrue & Tang Songcao & $1.62 \pm 0.37$ & 0.09 \\
\hline Artemisia scoparia Waldst. et Kit. & Virgate Sagebrush & Zhu Maohao & $1.13 \pm 0.28$ & 0.06 \\
\hline
\end{tabular}

Data \pm standard deviation were the average of three sample lines and each line had 10 sample plots.

Leymus chinensis (7.00\%), 93.77 for Serratula centauroides (6.12\%), 92.72 for Achnatherum sibiricum (6.05\%), while other grasses were below $93.00 \mathrm{~kg} / \mathrm{hm}^{2}$ in MS. On the other hand, Stipa grandi, Stipa krylovii, Cleistogenes squarrosa, Anemarrhena asphodeloides were the dominant grasses in TS, their DM yield at a high level of order were $1147.04 \mathrm{~kg} / \mathrm{hm}^{2}$ for Stipa grandis (61.27\%), 428.66 for Stipa krylovii (22.90\%), 122.17 for Cleistogenes squarrosa
(6.53\%), 79.96 for Anemarrhena asphodeloides (4.27\%), while other grasses were below $47.84 \mathrm{~kg} / \mathrm{hm}^{2}$ in TS. The minimum DM yields were observed from Potentilla tanacetifolia (11.29\%) in MS and from Artemisia scoparia (1.13\%) in TS, respectively.

\section{Chemical composition of natural grasses}

Chemical composition of natural grasses in MS and TS are shown 
in Table 2. The DM of natural grasses were $29.45 \%$ to $67.94 \%$ in MS and were $23.09 \%$ to $47.92 \%$ in TS on a FM basis. In meadow steppe, the highest and the lowest moisture were found in Adenophora stenanthina at $65.30 \%$ and Carex tristachya at $34.37 \%$ of FM. In TS, the highest and the lowest moisture were found in Thalictrum aquilegifolium at $63.33 \%$ and Agropyron cristatum at $47.34 \%$ of FM. The OM of both steppes were similar ranging from $84.38 \%$ to $96.79 \%$ on a DM basis, their ether extract (EE) were $1.30 \%$ to $3.06 \%$ of DM. The CP of Silene conoidea was the lowest content at 3.93\% in MS while other grasses were $7.12 \%$ to $12.77 \%$ of DM. The NDF and ADF were $37.04 \%$ to $69.86 \%$ of DM and $24.04 \%$ to $48.95 \%$ in MS, and were $44.79 \%$ to $73.33 \%$ and $37.64 \%$ to $52.19 \%$ of DM in TS, respectively.

Chemical composition of mixed natural grasses in MS and TS are shown in Table 3. The DM contents of mixed grasses were similar levels ranging from $52.40 \%$ to $55.07 \%$, and their OM

Table 2. Chemical composition of natural grasses in meadow and typical steppe

\begin{tabular}{|c|c|c|c|c|c|c|}
\hline Grass species & DM (\%) & OM (\% DM) & $\mathrm{CP}(\% \mathrm{DM})$ & $\mathrm{EE}(\% \mathrm{DM})$ & NDF (\% DM) & ADF (\% DM) \\
\hline \multicolumn{7}{|l|}{ Meadow steppe } \\
\hline Stipa Baicalensis Roshev & $57.94 \pm 0.08$ & $95.37 \pm 0.17$ & $8.76 \pm 0.19$ & $2.55 \pm 0.05$ & $69.86 \pm 0.53$ & $41.34 \pm 0.57$ \\
\hline Leymus chinensis (Trin.) Tzvel. & $57.80 \pm 1.42$ & $95.97 \pm 0.27$ & $10.09 \pm 0.06$ & $2.64 \pm 0.11$ & $62.19 \pm 0.17$ & $36.92 \pm 0.64$ \\
\hline Serratula centauroides L. & $34.64 \pm 1.46$ & $94.37 \pm 0.59$ & $10.09 \pm 0.06$ & $2.31 \pm 0.13$ & $38.02 \pm 1.88$ & $25.31 \pm 1.20$ \\
\hline Achnatherum sibiricum (L.) Keng & $48.45 \pm 0.96$ & $95.53 \pm 0.23$ & $9.21 \pm 0.46$ & $2.79 \pm 0.05$ & $59.28 \pm 0.43$ & $35.06 \pm 0.61$ \\
\hline Cleistogenes squarrosa (Trin.) Keng & $55.39 \pm 0.54$ & $91.77 \pm 0.02$ & $9.54 \pm 0.12$ & $2.40 \pm 0.03$ & $61.34 \pm 0.32$ & $37.29 \pm 1.18$ \\
\hline Pulsatilla turczaninovii Kryl. et Serg. & $67.94 \pm 0.28$ & $89.97 \pm 0.81$ & $8.92 \pm 0.20$ & $2.04 \pm 0.09$ & $37.93 \pm 0.32$ & $24.04 \pm 0.51$ \\
\hline Carex tristachya Thunb. & $57.61 \pm 0.27$ & $94.17 \pm 0.29$ & $9.73 \pm 0.09$ & $2.74 \pm 0.03$ & $58.03 \pm 0.15$ & $39.17 \pm 0.60$ \\
\hline Poa annua L. & $52.04 \pm 0.30$ & $92.74 \pm 0.27$ & $7.12 \pm 0.02$ & $1.93 \pm 0.06$ & $58.33 \pm 0.95$ & $35.17 \pm 0.55$ \\
\hline Melissilus ruthenicus (L.) Peschkova Trigonella ruthenica L.) & $45.34 \pm 0.40$ & $94.14 \pm 0.27$ & $11.73 \pm 0.04$ & $2.61 \pm 0.09$ & $47.39 \pm 0.02$ & $31.25 \pm 0.48$ \\
\hline Adenophora stenanthina (Ledeb.) Kitagawa & $29.45 \pm 0.33$ & $94.38 \pm 0.37$ & $10.80 \pm 0.08$ & $2.67 \pm 0.06$ & $47.54 \pm 0.31$ & $36.09 \pm 0.21$ \\
\hline Astragalus melilotoides Pall. & $36.51 \pm 0.05$ & $95.91 \pm 0.17$ & $12.08 \pm 0.02$ & $1.87 \pm 0.02$ & $59.73 \pm 0.17$ & $48.95 \pm 0.29$ \\
\hline Thalictrum aquilegifolium L. var. sibiricum Regel et Tiling & $53.27 \pm 0.47$ & $92.43 \pm 0.14$ & $10.35 \pm 0.18$ & $2.11 \pm 0.03$ & $40.12 \pm 0.24$ & $24.59 \pm 0.66$ \\
\hline Artemisia frigida (Willd.) Bess & $37.03 \pm 0.62$ & $94.74 \pm 0.17$ & $10.77 \pm 0.19$ & $2.56 \pm 0.07$ & $50.17 \pm 0.68$ & $24.69 \pm 0.79$ \\
\hline Iris ventricosa Pall. & $37.64 \pm 0.23$ & $93.27 \pm 0.01$ & $9.12 \pm 0.05$ & $2.77 \pm 0.24$ & $53.23 \pm 1.02$ & $40.17 \pm 1.11$ \\
\hline Astragalus adsurgens Pall. & $43.78 \pm 0.40$ & $93.24 \pm 0.18$ & $11.33 \pm 0.08$ & $1.99 \pm 0.02$ & $57.34 \pm 0.40$ & $40.59 \pm 0.28$ \\
\hline Potentilla acaulis L. & $50.17 \pm 0.41$ & $85.93 \pm 0.41$ & $9.37 \pm 0.02$ & $3.02 \pm 0.05$ & $54.11 \pm 0.57$ & $34.52 \pm 0.40$ \\
\hline Oxytropis myriophylla (Pall.) DC. & $51.19 \pm 0.21$ & $93.52 \pm 0.20$ & $12.77 \pm 0.40$ & $1.78 \pm 0.01$ & $52.09 \pm 0.21$ & $31.27 \pm 0.36$ \\
\hline Carex chinensis Retz. & $39.32 \pm 0.40$ & $93.48 \pm 0.69$ & $8.89 \pm 0.50$ & $2.12 \pm 0.33$ & $57.33 \pm 0.40$ & $48.20 \pm 0.47$ \\
\hline Bupleurum scorzonerifolium Willd. & $38.50 \pm 0.22$ & $94.10 \pm 0.76$ & $11.30 \pm 0.15$ & $2.04 \pm 0.30$ & $42.09 \pm 0.27$ & $28.95 \pm 0.05$ \\
\hline Koeleria cristata (L.) Pers. & $60.00 \pm 0.59$ & $95.77 \pm 0.12$ & $9.02 \pm 0.19$ & $2.03 \pm 0.05$ & $62.35 \pm 0.89$ & $37.14 \pm 0.53$ \\
\hline Ixeris polycephala Cass. & $31.20 \pm 0.40$ & $89.73 \pm 0.25$ & $10.75 \pm 0.30$ & $2.81 \pm 0.05$ & $56.82 \pm 0.30$ & $49.03 \pm 0.69$ \\
\hline Veronica incana $\mathrm{L}$. & $50.33 \pm 0.25$ & $90.17 \pm 0.24$ & $8.82 \pm 0.11$ & $2.09 \pm 0.02$ & $47.05 \pm 0.10$ & $35.39 \pm 0.40$ \\
\hline Gentiana dahurica Fisch. & $44.29 \pm 0.43$ & $88.82 \pm 0.24$ & $10.67 \pm 0.37$ & $3.02 \pm 0.06$ & $43.28 \pm 0.43$ & $37.35 \pm 0.39$ \\
\hline Scorzonera Subacaulis (Regel.) Lipsch. & $39.29 \pm 0.42$ & $92.34 \pm 0.59$ & $11.07 \pm 0.08$ & $3.06 \pm 0.19$ & $37.04 \pm 0.58$ & $27.53 \pm 0.29$ \\
\hline Cymbaria dahurica L. & $41.93 \pm 0.05$ & $88.89 \pm 1.51$ & $9.56 \pm 0.07$ & $1.54 \pm 0.03$ & $43.98 \pm 0.02$ & $31.27 \pm 0.41$ \\
\hline Sanguisorba officinalis L. & $33.27 \pm 0.14$ & $89.53 \pm 0.32$ & $9.13 \pm 0.31$ & $2.74 \pm 0.09$ & $52.39 \pm 3.25$ & $37.09 \pm 0.79$ \\
\hline Scutellaria scordifolia Fisch. ex Schrenk. & $49.38 \pm 0.36$ & $84.38 \pm 0.28$ & $10.89 \pm 0.07$ & $2.28 \pm 0.02$ & $40.17 \pm 0.08$ & $29.33 \pm 0.39$ \\
\hline Agropyron cristatum (L.) Gaertn. & $56.45 \pm 0.37$ & $95.45 \pm 0.27$ & $9.56 \pm 0.27$ & $2.43 \pm 0.06$ & $62.13 \pm 0.13$ & $37.09 \pm 0.25$ \\
\hline Heteropappus altaicus (Willd.) Novopokr & $47.34 \pm 0.32$ & $90.77 \pm 0.42$ & $11.67 \pm 0.06$ & $2.10 \pm 0.03$ & $39.30 \pm 0.26$ & $28.89 \pm 0.11$ \\
\hline Galium verum L. & $51.74 \pm 0.17$ & $92.08 \pm 0.16$ & $10.78 \pm 0.43$ & $3.03 \pm 0.12$ & $47.28 \pm 0.47$ & $35.05 \pm 0.42$ \\
\hline Silene conoidea L. & $30.77 \pm 0.25$ & $96.79 \pm 1.17$ & $3.93 \pm 0.01$ & $1.30 \pm 0.01$ & $47.45 \pm 0.25$ & $38.41 \pm 0.27$ \\
\hline Allium tenuissimum $\mathrm{L}$. & $33.47 \pm 0.22$ & $90.75 \pm 0.16$ & $10.54 \pm 0.25$ & $2.43 \pm 0.20$ & $40.45 \pm 0.33$ & $32.93 \pm 0.35$ \\
\hline Potentilla tanacetifolia Willd. ex Schlecht. & $31.18 \pm 0.16$ & $89.73 \pm 0.16$ & $9.37 \pm 0.05$ & $2.72 \pm 0.05$ & $52.09 \pm 1.29$ & $33.33 \pm 0.44$ \\
\hline \multicolumn{7}{|l|}{ Typical steppe } \\
\hline Stipa grandis P. Smirn. & $44.73 \pm 0.40$ & $93.29 \pm 0.04$ & $10.29 \pm 0.15$ & $2.33 \pm 0.09$ & $68.30 \pm 0.06$ & $47.01 \pm 0.69$ \\
\hline Stipa krylovii Roshev & $47.32 \pm 0.39$ & $92.77 \pm 0.09$ & $9.56 \pm 0.27$ & $2.73 \pm 0.08$ & $73.33 \pm 0.38$ & $52.19 \pm 0.07$ \\
\hline Cleistogenes squarrosa (Trin.) Keng & $41.35 \pm 0.07$ & $93.06 \pm 0.41$ & $9.05 \pm 0.23$ & $2.14 \pm 0.11$ & $67.23 \pm 0.47$ & $43.92 \pm 0.07$ \\
\hline Anemarrhena asphodeloides Bunge & $47.92 \pm 0.42$ & $93.23 \pm 0.03$ & $10.12 \pm 0.05$ & $3.05 \pm 0.29$ & $69.92 \pm 0.06$ & $40.35 \pm 0.16$ \\
\hline Leymus chinensis (Trin.) Tzvel. & $43.29 \pm 0.28$ & $88.37 \pm 0.84$ & $10.03 \pm 0.20$ & $3.04 \pm 0.24$ & $66.29 \pm 0.03$ & $39.84 \pm 0.63$ \\
\hline Allium tenuissimum $\mathrm{L}$. & $23.09 \pm 0.08$ & $89.77 \pm 0.10$ & $11.57 \pm 0.13$ & $2.58 \pm 0.17$ & $57.59 \pm 0.25$ & $46.32 \pm 0.14$ \\
\hline Agropyron cristatum (L.) Gaertn. & $35.31 \pm 0.03$ & $92.38 \pm 0.17$ & $8.34 \pm 0.28$ & $2.51 \pm 0.05$ & $69.34 \pm 0.39$ & $45.03 \pm 0.21$ \\
\hline Thalictrum aquilegifolium L. var. sibiricum Regel et Tiling & $30.10 \pm 0.11$ & $85.43 \pm 0.02$ & $10.29 \pm 0.16$ & $3.02 \pm 0.05$ & $50.32 \pm 0.60$ & $37.64 \pm 0.63$ \\
\hline Artemisia scoparia Waldst. et Kit. & $45.05 \pm 0.19$ & $94.75 \pm 0.33$ & $8.35 \pm 0.25$ & $2.34 \pm 0.06$ & $44.79 \pm 0.14$ & $38.83 \pm 0.75$ \\
\hline
\end{tabular}

$\mathrm{DM}$, dry matter; $\mathrm{OM}$, organic matter; $\mathrm{CP}$, crude protein; $\mathrm{EE}$, ether extract; $\mathrm{NDF}$, neutral detergent fiber; $\mathrm{ADF}$, acid detergent fiber.

Data \pm standard deviation are the average of three grasses samples. 
Table 3. Chemical composition of mixed grasses in meadow and typical steppe

\begin{tabular}{|c|c|c|c|c|c|c|c|}
\hline Material & DM (\%) & OM (\% DM) & CP (\% DM) & EE (\% DM) & NDF (\% DM) & ADF (\% DM) & WSC (\% DM) \\
\hline \multicolumn{8}{|l|}{ Meadow steppe } \\
\hline Small-scale & $52.49 \pm 0.35^{b}$ & $95.24 \pm 0.04^{b}$ & $8.91 \pm 0.02^{b}$ & $2.40 \pm 0.05^{\mathrm{ab}}$ & $69.47 \pm 0.16^{a}$ & $47.29 \pm 1.27^{\mathrm{a}}$ & $2.20 \pm 0.02^{\mathrm{a}}$ \\
\hline Round bale & $55.07 \pm 1.14^{\mathrm{a}}$ & $95.27 \pm 0.08^{b}$ & $9.03 \pm 0.01^{\mathrm{a}}$ & $2.48 \pm 0.09^{\mathrm{a}}$ & $69.09 \pm 0.61^{a}$ & $47.06 \pm 0.66^{a}$ & $2.15 \pm 0.01^{\mathrm{a}}$ \\
\hline \multicolumn{8}{|l|}{ Typical steppe } \\
\hline Small-scale & $53.00 \pm 0.44^{\mathrm{ab}}$ & $95.69 \pm 0.03^{\mathrm{a}}$ & $8.02 \pm 0.06^{d}$ & $2.13 \pm 0.09^{c}$ & $67.32 \pm 0.13^{b}$ & $43.47 \pm 0.94^{b}$ & $2.02 \pm 0.01^{b}$ \\
\hline Round bale & $53.15 \pm 0.61^{a b}$ & $95.73 \pm 0.04^{a}$ & $8.13 \pm 0.02^{c}$ & $2.19 \pm 0.05^{b c}$ & $66.75 \pm 0.20^{b}$ & $43.33 \pm 0.98^{b}$ & $2.04 \pm 0.02^{b}$ \\
\hline
\end{tabular}

$\mathrm{DM}$, dry matter; OM, organic matter; $\mathrm{CP}$, crude protein; $\mathrm{EE}$, ether extract; NDF, neutral detergent fiber; ADF, acid detergent fiber; WSC, water-soluble carbohydrate. Data \pm standard deviation are means of three grasses samples.

${ }^{a-d}$ Means \pm standard deviation within columns with different superscript letters differ $(p<0.05)$

were also similar with $95 \%$ of DM in both steppes. The CP of mixed grasses were $8.91 \%$ to $9.03 \%$ in MS and were $8.02 \%$ to $8.13 \%$ in TS. Their NDF and ADF were $69 \%$ and $47 \%$ of DM in MS, while they were lower more than about $2 \%$ and $4 \%$ of DM in TS. The WSC contents of mixed grasses in MS $(2.15 \%$ to $2.20 \%$ of $\mathrm{DM})$ were higher $(\mathrm{p}<0.05)$ than that in TS $(2.02 \%$ to $2.04 \%$ of DM).

Fermentation quality of mixed grasses silage prepared without or with LAB and cellulase in MS and TS are shown in Table 4. The grasses $(\mathrm{G})$, preparation methods $(\mathrm{P})$, additives $(\mathrm{A})$ and their interaction $(\mathrm{G} \times \mathrm{P}, \mathrm{G} \times \mathrm{A}, \mathrm{A} \times \mathrm{P}$, and $\mathrm{G} \times \mathrm{A} \times \mathrm{P})$ influenced $(\mathrm{p}<0.001)$ butyric acid, in addition the additives also influenced $(\mathrm{p}<0.001)$ $\mathrm{pH}$, lactic acid, and ammonia-N content. The small-scale and round bale silages in both steppes were showed as similar fermentation results. After 60 days of ensiling, the $\mathrm{CH}, \mathrm{AC}$, and $\mathrm{CH}+\mathrm{AC}$ treatments of small-scale silages and round bale silages in MS and TS were preserved with significantly $(\mathrm{p}<0.05)$ lower $\mathrm{pH}$ and ammonia- $\mathrm{N}$ content, and significantly $(\mathrm{p}<0.05)$ higher lactic acid content than those of control. Acetic acid were produced in all silages with $0.38 \%$ to $0.57 \%$ of FM. Only the control treatment in MS had detected butyric acid $(0.16 \%$ to $0.25 \%$ of FM) and propionic acid ( $0.11 \%$ to $0.17 \%$ of FM).

Chemical composition of mixed natural grasses silage in MS and TS were shown in Table 5. The additives influenced $(\mathrm{p}<0.001)$ $\mathrm{CP}, \mathrm{EE}, \mathrm{NDF}$, and $\mathrm{ADF}$. The OM contents of all silages were similar levels raging $92.89 \%$ to $95.13 \%$ of DM. The CP contents of MS silages $(8.13 \%$ to $8.92 \%$ of DM) were significantly $(\mathrm{p}<0.05)$ higher than in the TS silages (7.22\% to $7.89 \%$ of DM). The CP contents of $\mathrm{CH}+\mathrm{AC}$-treated silages were significantly higher $(\mathrm{p}<0.05)$ than other treatments, and MS had higher $(\mathrm{p}<0.05)$ $\mathrm{CP}$ content in the four typies of silages. $\mathrm{AC}-$ and $\mathrm{CH}+\mathrm{AC}$ - treated silages significantly $(\mathrm{p}<0.05)$ decreased NDF and ADF contents compared to the control or $\mathrm{CH}$-treatment.

\section{DUSICUSSION}

Natural steppes, such as MS and TS, are important feed sources for livestock, and most of the local livestock in China are depen- dent on these environments. MS occur in the eastern part of the grassland belt, extending westward to the eastern edge of the Inner Mongolian Plateau, China [19,20]. It is reported that the structural species in MS was Sibirian filifolium, and the dominant grasses were Stipa baicalensis and Leymus chinensis. Our study found that the MS contained 33 species of natural grasses, dominated by Stipa baicalensis and Leymus chinensis. However, we did not observe the structural species Sibirian filifolium due to steppe environmental degradation [21].

TS are located west of MS in the Inner Mongolian Plateau. Previous studies have reported the structural species as Stipa grandi and the dominant grasses as Stipa grandi, Stipa krylovii, and Cleistogenes squarrosa [22-24]. We found nine species of natural grasses, dominated by Stipa grandi, Stipa krylovii, Cleistogenes squarrosa, and Anemarrhena asphodeloides, which is consistent with previous studies [25-27]. The structural species had shifted from Compositae to Gramineae, which may lead to easier ensiling. The TS had fewer species than the MS, and the species of Gramineae accounted for a large percentage of total grasses, which could reduce the abundance of other grass species that have an uncertain value for ensiling [28].

Yield is the dominant factor affecting the quality of ensiling [20]. The DM yield of Stipa baicalensis, Leymus chinensis, Serratula centauroides, Achnatherum sibiricum, and Cleistogenes squarrosa accounted for $35.41 \%$ of the whole DM yield in MS, whereas Stipa grandi and Stipa kryloviiin accounted for $84.17 \%$ of the whole DM yield in TS.

Generally, natural grasses do not grow during the cold season because of the low winter temperatures. Therefore, it is necessary to preserve a feed supply to continuously feed ruminants during the cold season. Silage fermentation is considered the most effective technique for addressing the cold season feed shortage [29].

Silage is now the most common preserved feed for cattle production in many countries, including China [30]. Generally, farm silage is based on natural lactic acid fermentation, in which epiphytic LAB convert WSC into organic acid during the ensiling process. The epiphytic LAB population density has become an important factor in predicting whether to apply LAB in silage 
Table 4. Fermentation quality of mixed grasses silage in meadow steppe and typical steppe ${ }^{1)}$

\begin{tabular}{|c|c|c|c|c|c|c|c|c|}
\hline Silage & Treatment & DM (\%) & $\mathrm{pH}$ & $\begin{array}{c}\text { Lactic acid } \\
(\% \mathrm{FM})\end{array}$ & $\begin{array}{c}\text { Acetic acid } \\
\text { (\% FM) }\end{array}$ & $\begin{array}{c}\text { Propionic acid } \\
\text { (\% FM) }\end{array}$ & $\begin{array}{c}\text { Butyric acid } \\
\text { (\% FM) }\end{array}$ & $\begin{array}{l}\text { Ammonia-N } \\
\text { (g/kg of } F M)\end{array}$ \\
\hline \multicolumn{9}{|l|}{ Meadow steppe } \\
\hline \multirow[t]{3}{*}{ Small scale } & Control & $50.36 \pm 0.01$ & $4.63 \pm 0.08^{\mathrm{a}}$ & $0.56 \pm 0.01^{\mathrm{fg}}$ & $0.38 \pm 0.01$ & $0.11 \pm 0.08^{b}$ & $0.16 \pm 0.00$ & $0.56 \pm 0.04^{\mathrm{a}}$ \\
\hline & $A C$ & $50.21 \pm 1.10$ & $4.32 \pm 0.26^{c}$ & $0.66 \pm 0.08^{e f}$ & $0.50 \pm 0.07$ & ND & ND & $0.14 \pm 0.04^{\text {cde }}$ \\
\hline & $\mathrm{CH}+\mathrm{AC}$ & $51.21 \pm 0.09$ & $4.13 \pm 0.06^{\mathrm{de}}$ & $1.11 \pm 0.03^{\mathrm{a}}$ & $0.55 \pm 0.02$ & ND & ND & $0.12 \pm 0.02^{\mathrm{de}}$ \\
\hline \multirow{2}{*}{ Round bale } & $A C$ & $51.32 \pm 0.24$ & $4.27 \pm 0.14^{\text {cd }}$ & $0.73 \pm 0.13^{\mathrm{de}}$ & $0.51 \pm 0.03$ & ND & ND & $0.17 \pm 0.02^{\text {cd }}$ \\
\hline & $\mathrm{CH}+\mathrm{AC}$ & $51.50 \pm 0.31$ & $4.16 \pm 0.17^{\text {de }}$ & $1.10 \pm 0.04^{\mathrm{a}}$ & $0.50 \pm 0.02$ & ND & ND & $0.14 \pm 0.01^{\text {cde }}$ \\
\hline \multicolumn{9}{|l|}{ Typical steppe } \\
\hline \multirow[t]{2}{*}{ Small scale } & Control & $51.13 \pm 0.49$ & $4.45 \pm 0.16^{b}$ & $0.76 \pm 0.04^{d}$ & $0.47 \pm 0.02$ & ND & ND & $0.40 \pm 0.04^{b}$ \\
\hline & $\mathrm{CH}$ & $50.64 \pm 0.69$ & $4.17 \pm 0.08^{\mathrm{de}}$ & $0.97 \pm 0.02^{b}$ & $0.49 \pm 0.02$ & ND & ND & $0.12 \pm 0.01^{\mathrm{de}}$ \\
\hline \multirow{3}{*}{ Round bale } & $A C$ & $50.34 \pm 0.38$ & $4.19 \pm 0.03^{d}$ & $0.95 \pm 0.02^{b}$ & $0.50 \pm 0.07$ & ND & ND & $0.11 \pm 0.01^{\mathrm{de}}$ \\
\hline & $\mathrm{CH}+\mathrm{AC}$ & $50.92 \pm 0.26$ & $4.08 \pm 0.04^{e}$ & $1.13 \pm 0.03^{\mathrm{a}}$ & $0.53 \pm 0.06$ & ND & ND & $0.12 \pm 0.02^{\text {de }}$ \\
\hline & SEM & 0.5712 & 0.0778 & 0.0364 & 0.0391 & 0.0206 & 0.0016 & 0.0277 \\
\hline \multirow[t]{2}{*}{ Grass means } & Meadow steppe & $50.76 \pm 0.25^{a}$ & $4.36 \pm 0.05^{\mathrm{a}}$ & $0.78 \pm 0.05^{b}$ & $0.47 \pm 0.02^{b}$ & $0.04 \pm 0.01$ & $0.05 \pm 0.02$ & $0.27 \pm 0.04^{\mathrm{a}}$ \\
\hline & Typical steppe & $50.62 \pm 0.14^{b}$ & $4.21 \pm 0.21^{b}$ & $0.93 \pm 0.04^{\mathrm{a}}$ & $0.51 \pm 0.01^{\mathrm{a}}$ & 0 & 0 & $0.20 \pm 0.03^{b}$ \\
\hline \multirow[t]{2}{*}{ PM means } & Small scale & $50.57 \pm 0.23^{b}$ & $4.27 \pm 0.05$ & $0.85 \pm 0.04$ & $0.49 \pm 0.01$ & $0.01 \pm 0.01$ & $0.02 \pm 0.01$ & $0.23 \pm 0.04$ \\
\hline & Round bale & $50.80 \pm 0.14^{a}$ & $4.30 \pm 0.05$ & $0.87 \pm 0.05$ & $0.50 \pm 0.02$ & $0.02 \pm 0.01$ & $0.03 \pm 0.02$ & $0.23 \pm 0.03$ \\
\hline \multirow[t]{4}{*}{ Additive means } & Control & $50.60 \pm 0.18$ & $4.58 \pm 0.04^{\mathrm{a}}$ & $0.59 \pm 0.04^{d}$ & $0.45 \pm 0.02$ & $0.07 \pm 0.02$ & $0.10 \pm 0.03$ & $0.50 \pm 0.02^{\mathrm{a}}$ \\
\hline & $\mathrm{CH}$ & $50.56 \pm 0.36$ & $4.19 \pm 0.05^{b c}$ & $0.93 \pm 0.04^{b}$ & $0.47 \pm 0.02$ & 0 & 0 & $0.17 \pm 0.02^{b}$ \\
\hline & $A C$ & $50.57 \pm 0.34$ & $4.27 \pm 0.19^{b}$ & $0.79 \pm 0.04^{c}$ & $0.50 \pm 0.02$ & 0 & 0 & $0.14 \pm 0.01^{b c}$ \\
\hline & $\mathrm{CH}+\mathrm{AC}$ & $51.01 \pm 0.17$ & $4.11 \pm 0.09^{c}$ & $1.12 \pm 0.01^{\mathrm{a}}$ & $0.54 \pm 0.02$ & 0 & 0 & $0.11 \pm 0.01^{c}$ \\
\hline & $G \times A \times P$ & 0.77 & 0.27 & 0.07 & 0.73 & $<0.001$ & $<0.001$ & 0.58 \\
\hline
\end{tabular}

DM, dry matter; FM, fresh matter; CH, Chikuso-1 inoculant, Lactobacillus plantarum, Snow Brand Seed Co. Ltd, Sapporo, Japan; ND, not detected; AC, Acremonium cellulase, Meiji Seika Pharma Co., Ltd, Tokyo, Japan; SEM, standard error of the mean; PM, preparation method of silage.

1) Silage was stored for $60 \mathrm{~d}$; data are the average of three silage samples.

${ }^{a-9}$ Means \pm standard deviation within columns with different superscript letters differ $(p<0.05)$.

[31]. LAB population densities $\geq 10^{5}$ (cfu)/g FM usually result in silage that is well preserved [14]. WSC is also an important factor that influences the fermentation quality of silage [32]. A good silage needs a DM $>5 \%$ WSC for lactic acid fermentation [33]. However, these mixed natural grasses have a relatively low WSC (Table 3). Furthermore, only a few epiphytic LAB are found on these materials [34], suggesting that silage fermentation may need to be improved using LAB inoculants or cellulase enzymes [14].

The LAB- and cellulase-treated silages in both steppes were well preserved, with significantly $(\mathrm{p}<0.05)$ lower $\mathrm{pH}$ and ammonia nitrogen content and significantly $(\mathrm{p}<0.05)$ higher lactic acid content than that of each control. These results are likely explained by the WSC content of the materials and by the numbers and physiological properties of epiphytic LAB. The low WSC content of the mixed grasses could hardly provide enough substrate for LAB fermentation. Added cellulase may degrade the cytoderm and increase the available sugars, thereby providing a substrate for lactic acid fermentation, which is consistent with what Sun et al. found for maize silage [35]. Furthermore, the population of epiphytic LAB is usually very low, and some lactic acid-producing cocci cannot not grow in a $\mathrm{pH}<4.5$. During silage fermentation, the cocci grew rapidly only in the early stage. If the silage $\mathrm{pH}$ remained $>4.0$, then the growth of clostridia was not inhibited, and butyric acid fermentation occurred.

In MS, the control silages were of poor quality, with a high 
Table 5. Chemical composition of mixed grasses silage in meadow and typical steppe ${ }^{1)}$

\begin{tabular}{|c|c|c|c|c|c|c|}
\hline \multirow{2}{*}{ Silage } & \multirow{2}{*}{ Treatment } & \multicolumn{5}{|c|}{ Chemical composition ( $\%$ of DM) } \\
\hline & & $\mathrm{OM}$ & $\mathrm{CP}$ & EE & NDF & ADF \\
\hline \multicolumn{7}{|l|}{ Meadow steppe } \\
\hline & $\mathrm{CH}$ & $93.37 \pm 0.28^{\mathrm{ef}}$ & $8.85 \pm 0.02^{\mathrm{a}}$ & $2.24 \pm 0.03^{\mathrm{ab}}$ & $64.28 \pm 0.02^{\mathrm{ab}}$ & $42.74 \pm 0.57^{\text {cde }}$ \\
\hline & $\mathrm{AC}$ & $92.89 \pm 0.29^{\dagger}$ & $8.71 \pm 0.10^{\mathrm{a}}$ & $2.22 \pm 0.07^{\mathrm{ab}}$ & $62.29 \pm 0.01^{\mathrm{abcd}}$ & $40.65 \pm 0.16^{\mathrm{ef}}$ \\
\hline & $\mathrm{CH}+\mathrm{AC}$ & $92.90 \pm 0.09^{f}$ & $8.92 \pm 0.03^{\mathrm{a}}$ & $2.19 \pm 0.07^{\mathrm{ab}}$ & $60.74 \pm 0.01^{\mathrm{cd}}$ & $40.12 \pm 0.05^{f}$ \\
\hline & $A C$ & $94.53 \pm 0.01^{\mathrm{abc}}$ & $8.75 \pm 0.00^{\mathrm{a}}$ & $2.27 \pm 0.08^{\mathrm{a}}$ & $63.40 \pm 0.01^{\mathrm{abc}}$ & $42.14 \pm 0.07^{\text {cde }}$ \\
\hline & $\mathrm{CH}+\mathrm{AC}$ & $95.13 \pm 0.42^{\mathrm{a}}$ & $8.92 \pm 0.13^{\mathrm{a}}$ & $2.12 \pm 0.02^{b c}$ & $61.36 \pm 1.03^{\mathrm{bcd}}$ & $40.77 \pm 0.05^{e}$ \\
\hline \multicolumn{7}{|l|}{ Typical steppe } \\
\hline \multirow[t]{2}{*}{ Small-scale } & Control & $93.65 \pm 0.45^{\text {cdef }}$ & $7.22 \pm 0.64^{\dagger}$ & $2.11 \pm 0.02^{b c}$ & $65.31 \pm 0.09^{\mathrm{a}}$ & $43.35 \pm 0.72^{\mathrm{abcd}}$ \\
\hline & $\mathrm{CH}$ & $94.05 \pm 0.64^{\text {bcde }}$ & $7.45 \pm 0.07^{\text {def }}$ & $2.00 \pm 0.01^{c d}$ & $63.18 \pm 0.19^{\mathrm{abc}}$ & $43.16 \pm 0.07^{\mathrm{bcd}}$ \\
\hline \multirow{3}{*}{ Round bale } & $A C$ & $94.10 \pm 0.56^{\text {bcde }}$ & $7.49 \pm 0.21^{\text {def }}$ & $2.04 \pm 0.03^{b c}$ & $63.47 \pm 0.32^{\mathrm{abc}}$ & $42.64 \pm 0.23^{\text {cde }}$ \\
\hline & $\mathrm{CH}+\mathrm{AC}$ & $94.59 \pm 0.38^{\mathrm{ab}}$ & $7.52 \pm 0.12^{d}$ & $1.93 \pm 0.02^{\mathrm{e}}$ & $61.88 \pm 0.01^{\text {cde }}$ & $41.32 \pm 0.03^{\text {def }}$ \\
\hline & SEM & 0.27 & 0.17 & 0.04 & 0.99 & 0.63 \\
\hline \multirow[t]{2}{*}{ Grass means } & Meadow steppe & $93.88 \pm 0.19^{b}$ & $8.59 \pm 0.09^{\mathrm{a}}$ & $2.24 \pm 0.02^{\mathrm{a}}$ & $63.25 \pm 0.49^{\mathrm{a}}$ & $42.23 \pm 0.40^{b}$ \\
\hline & Typical steppe & $94.15 \pm 0.09^{a}$ & $7.60 \pm 0.09^{b}$ & $2.02 \pm 0.02^{b}$ & $63.06 \pm 0.44^{b}$ & $42.49 \pm 0.36^{\mathrm{a}}$ \\
\hline \multirow[t]{2}{*}{ PM means } & Small scale & $93.59 \pm 0.14^{b}$ & $8.08 \pm 0.14$ & $2.13 \pm 0.03$ & $62.65 \pm 0.53^{b}$ & $41.79 \pm 0.34^{b}$ \\
\hline & Round bale & $94.46 \pm 0.10^{\mathrm{a}}$ & $8.06 \pm 0.13$ & $2.12 \pm 0.03$ & $63.65 \pm 0.03^{\mathrm{a}}$ & $42.95 \pm 0.38^{\mathrm{a}}$ \\
\hline \multirow[t]{4}{*}{ Additive means } & Control & $93.91 \pm 0.18^{b}$ & $7.72 \pm 0.14^{b}$ & $2.21 \pm 0.13^{\mathrm{a}}$ & $64.94 \pm 0.41^{a}$ & $44.31 \pm 0.52^{\mathrm{a}}$ \\
\hline & $\mathrm{CH}$ & $94.07 \pm 0.17^{\mathrm{a}}$ & $8.05 \pm 0.19^{\mathrm{ab}}$ & $2.10 \pm 0.04^{\mathrm{ab}}$ & $64.17 \pm 0.65^{a}$ & $42.95 \pm 0.97^{b}$ \\
\hline & $\mathrm{AC}$ & $93.86 \pm 0.19^{b}$ & $8.09 \pm 0.20^{\mathrm{ab}}$ & $2.14 \pm 0.04^{\mathrm{ab}}$ & $62.60 \pm 0.40^{b}$ & $41.70 \pm 0.92^{c}$ \\
\hline & $\mathrm{CH}+\mathrm{AC}$ & $94.25 \pm 0.29^{a}$ & $8.41 \pm 0.19^{\mathrm{a}}$ & $2.05 \pm 0.04^{b}$ & $60.90 \pm 0.43^{c}$ & $40.51 \pm 0.10^{d}$ \\
\hline & $G \times A \times P$ & 0.25 & 0.79 & 0.64 & 0.78 & 0.80 \\
\hline
\end{tabular}

DM, dry matter; OM, organic matter; CP, crude protein; EE, ether extract; NDF, neutral detergent fiber; ADF, acid detergent fiber; $C H$, Chikuso-1 inoculant, Lactobacillus plantarum, Snow Brand Seed Co. Ltd, Sapporo, Japan; AC, Acremonium cellulase, Meiji Seika Pharma Co., Ltd, Tokyo, Japan; SEM, standard error of the mean; PM, preparation method of silage.

1) Silage was stored for $60 \mathrm{~d}$; data are the average of three silage samples.

${ }^{a-f}$ Means \pm standard deviation within columns with different superscript letters differ $(p<0.05)$.

butyric acid content. These results suggest that the inoculant strain Chikuso-1 used in this study is Lactobacilli plnatarum, as it can promote lactic acid fermentation as a homofermentative lactic bacteria and may grow in a low-pH environment $[36,37]$. Therefore, inoculating silage with these strains may result in beneficial effects by promoting the propagation of LAB and by inhibiting the growth of clostridia, as well as by decreasing ammonia nitrogen, which is an indicator of high-quality fermentation $[38,39]$. The combination of LAB and cellulase had a greater effect than did treatment with either one alone, showing that these additives promote each other to improve silage fermentation.

The CP content was higher in treatment groups than in controls, and the NDF and ADF contents were lower than those in the controls reported in studies of alfalfa silages $[40,41]$. The CP content was greatest in the $\mathrm{CH}+\mathrm{AC}$ - silage, whereas there was no difference between $\mathrm{CH}$ - and $\mathrm{AC}$ - treatments, which is consistent with previous findings [35]. The lower NDF and ADF contents in the $\mathrm{CH}+\mathrm{AC}$ - and $\mathrm{AC}$ - treatments were probably the result of cellulose-promoted degradation of fiber, which is consistent with the results of Colonbatto [9].

Small-scale fermentation systems were developed and used for LAB screening and silage preparation, because this method can be easy to control under different fermentation conditions [14]. In this study, the silages were prepared using small-scale fermentation and round bale systems. The results showed that small-scale silage values were slightly greater than those observed 
in round bale silage, because round bale silage with plastic film allows some air permeability [42]. The similarities between the two kinds of silage showed that small-scale fermentation can be used to test the fermentation quality of silage.

These results confirmed that the addition of LAB, cellulase, and their combination benefited silage fermentation by increasing lactic acid, decreasing butyric acid and ammonia nitrogen contents, and improving the silage quality of natural grasses from MS and TS environments.

\section{CONCLUSION}

MS and TS contained 33 and 9 species of natural grasses, Stipa Baicalensis and Stipa grandi were the dominant grasses with the highest DM yield in each steppe. Their mixed grasses in both steppes had $8.02 \%$ to $9.03 \% \mathrm{CP}$ and $66.75 \%$ to $69.47 \% \mathrm{NDF}$ of $\mathrm{DM}$. LAB and cellulase, especially their combination could effectively improve fermentation quality of mixed grasses silage in both steppes.

\section{CONFLICT OF INTEREST}

We certify that there is no conflict of interest with any financial organization regarding the material discussed in the manuscript.

\section{ACKNOWLEDGMENTS}

This work was supported by Project of Agriculture Research System (CARS-35), China and the Demonstration of Silage Preparation Technology, Public Interest fund (201303061) for Agro-scientific Research, China. We thank Meiji Seika Pharma Co., Ltd., Tokyo, Japan for providing the commercial cellulase enzyme and Snow Brand Seed Co., Ltd, Sapporo, Japan for providing the commercial LAB inoculant.

\section{REFERENCES}

1. Zhang J, Guo G, Chen L, et al. Effect of applying lactic acid bacteria and propionic acid on fermentation quality and aerobic stability of oats-common vetch mixed silage on the Tibetan plateau. J Anim Sci 2015;86:595-602.

2. Scarbrough DA, Coblentz WK, Coffey KP, et al. Effects of summer management and fall harvest date on ruminal in situ degradation of crude protein in stockpiled bermudagrass. Anim Feed Sci Technol 2002;96:119-33

3. Kaiser AG, Curll ML. Improving the efficiency of forage conservation from pastures. In Wheeler JL, Pearson CJ, Robards GE, editors, Temperate pastures: their production, use and management. Melbourne, Australia; CSIRO Publishing Publishing, 1987. p. 397-411.

4. King C, McEniry J, O'Kiely P. A note on the fermentation characteristics of red clover silage in response to advancing stage of maturity in the primary growth. Irish J Agric Food Res 2012;51:79-84.
5. Filya I, Sucu E. The effects of lactic acid bacteria on the fermentation, aerobic stability and nutritive value of maize silage. Grass Forage Sci 2010;65:446-55.

6. Li M, Zi X, Zhou H, Hou G, Cai Y. Effects of sucrose, glucose, molasses and cellulase on fermentation quality and in vitro gas production of king grass silage. Anim Feed Sci Technol 2014;197:206-12.

7. Weinberg Z, Ashbell G, Hen Y, Azrieli A. The effect of cellulase and heicellulase plus pectinase on the aerobic stability and fiber analysis of peas and wheat silages. Anim Feed Sci Technol 1995;55:287-93.

8. Muck RE. Initial bacteria numbers on lucerne prior to ensiling. Grass Forage Sci 1989;44:19-25.

9. Colombatto D, Mould FL, Bhat MK, et al. Influence of fibrolytic enzymes on the hydrolysis and fermentation of pure celluloseand xylan by mixed ruminal microorganisms in vitro. J Anim Sci 2003;81: 1040-50.

10. Liu G, Xie X, Ye D, et al. Plant functional diversity and species diversity in the Mongolian steppe. PLoS ONE 2013;8:e77565.

11. Munson SM, Lauenroth WK. Plant Community recovery following restoration in semiarid grasslands. Res Ecol 2012;20:656-63.

12. Wang Z, Zhang Q, Xin X, et al. Response of the annual biomass production of a typical steppe plant community to precipitation fluctuations. Rangeland J 2014;36:527-36.

13. Cai Y. Analysis method for silage. In: Japanase Society of Grassland Science, editors. Field and laboratory methods for grassland science. Tokyo, Japan: Thsho Printing Co., Ltd.; 2004. p. 279-82.

14. Cai Y, Benno Y, Ogawa M, Kumai S. Effect of applying lactic acid bacteria isolated from forage crops on fermentation characteristics and aerobic deterioration of silage. J Dairy Sci 1999;82:520-6.

15. Horwitz W, Latimer Jr. GW. AOAC International. Official methods of analysis of AOAC International. 18th ed. Gaithersburg, MD: AOAC International; 2005.

16. Soest VJP, Robertson JB, Lewis BA. Methods fro dietary fiber, neutral detergent fiber and non-starch polysaccharides in relation to animal nutrition. J Dairy Sci 1991;74:3583-97.

17. Thomas T. An automated procedure for the determination of soluble carbohydrates in herbage. J Sci Food Agric 1997;28:639-42.

18. Saidin S, Kadir MRA, Sulaiman E, Kasim, NHA. Effects of different implant-abutment connections on micromotion and stress distribution: Prediction of microgap formation. J Dent 2012;40:467-74.

19. Wu X, Liu G, Butterbach-Bahl K, et al. Effects of land cover and soil properties on denitrification potential in soils of two semi-arid grasslands in Inner Mongolia, China. J Arid Environ 2013;92:98-101.

20. Zhou, TR. Analyze of bale silage manufactur technique and quality control of natural grassland herbage [master's thesis]. Hohhot, China: Inner Mongolia Agriculture University; 2015.

21. Buheaosi. Grassland resources and evaluation in Ewenke Autonomous Banner, 2 th ed. Beijing: China Agriculture Press; 2013.

22. Li X, Li G, Wang H, Wang H, Yu J. Influence of meadow changes on net primary productivity: a case study in a typical steppe area of XilinGol of Inner Mongolia in China. Geosciences J 2015;19:561-73.

23. Li F, Zeng Y, Luo JH, Ma RH, Wu BF. Modeling grassland aboveground biomass using a pure vegetation index. Ecol Indic 2016;62: 
279-88.

24. Zhang Q, Wu B, Nishino N, Wang X, Yu Z. Fermentation and microbial population dynamics during the ensiling of native grass and subsequent exposure to air. J Anim Sci 2016;87:389-97.

25. Zhu T. Grassland resources and development of grassland agriculture in temperate China. Rangelands 1998;10:124-7.

26. Goomaral A, Undarmaa J, Matsumoto T, Yamato M. Effect of plant species on communities of arbuscular mycorrhizal fungi in the Mongolian steppe. Mycoscience 2013;54:362-7.

27. Jin YX, Yang XC, Qiu JJ, et al. Remote sensing-based biomass estimation and its spatio-temporal variations in temperate grassland, Northern China. Remote Sens 2014;6:1496-513.

28. Cherney DJR, Alessi MA, Cherney JH. Influence of grass species and sample preparation on ensiling characteristics. Crop Sci 2006;46: 256-63.

29. Borreani G, Giaccone D, Mimosi A, Tabacco E. Comparison of hay and haylage from permanent Alpine meadows in winter dairy cow diets. J Dairy Sci 2007;90:5643-50.

30. McEniry J, Forristal PD, O'Kiely P. Factors influencing the conservation characteristics of baled and precision-chop grass silages. Irish J Agric Food Res 2011;50:175-88.

31. Weinberg ZG, Ashbell G, Azrieli A, Brukental I. Ensiling peas, ryegrass and wheat with additives of lactic acid bacteria (LAB) and cell wall degrading enzymes. Grass Forage Sci 1993;48:70-8.

32. McDonald P, Henderson AR. Determination of water-soluble carbohydrates in grass. J Sci Food Agric 1964;15:395-8.

33. Amer S, Hassanat F, Berthiaume R, Seguin P, Mustafa AF. Effects of water soluble carbohydrate content on ensiling characteristics, chemical composition and in vitro gas production of forage millet and forage sorghum silages. Anim Feed Sci Technol 2012;177:23-9.

34. Cao Y, Takahashi T, Horiguchi K-i, Yoshida N, Cai Y. Methane emi- ssions from sheep fed fermented or non-fermented total mixed ration containing whole-crop rice and rice bran. Anim Feed Sci Technol 2010;157:72-8

35. Sun ZH, Liu SM, Tayo GO, et al. Effects of cellulase or lactic acid bacteria on silage fermentation and in gas production of several morphological fractions of maize stover. Anim Feed Sci Technol 2009;152:219-31.

36. Napasirth V, Napasirth P, Sulinthone T, Phommachanh K, Cai YM. Microbial population, chemical composition and silage fermentation of cassava residues. J Anim Sci 2015;86:842-8.

37. Li DX, Ni KK, Pang HL, et al. Identification and antimicrobial activity detection of lactic acid bacteria isolated from corn stover silage. AsianAustralas J Anim Sci 2015;28:620-31.

38. Bureenok S, Yuangklang C, Vasupen K, Schonewille JT, Kawamoto $Y$. The effects of additives in napier grass silages on chemical composition, feed intake, nutrient digestibility and rumen fermentation. Asian-Australas J Anim Sci 2012;25:1248-54.

39. McEniry J, King C, O'Kiely P. Silage fermentation characteristics of three common grassland species in response to advancing stage of maturity and additive application. Grass Forage Sci 2014;69:393-404.

40. Cao LM, Goto M, Karita S, et al. Effect of fermented juice of epiphytic lactic acid bacteria on the fermentation quality of alfalfa (Medicago sativa L.) silage and its energy and nitrogen utilization by dry cows. Grass Forage Sci 2002;48:227-35.

41. Wang J, Wang JQ, Zhou H, Feng T. Effects of addition of previously fermented juice prepared from alfalfa on fermentation quality and protein degradation of alfalfa silage. Anim Feed Sci Technol 2009; 151:280-90.

42. Borreani G, Tabacco E. Improving corn silage quality in the top layer of farm bunker silos through the use of a next-generation barrier film with high impermeability to oxygen. J Dairy Sci 2014;97:2415-26. 